ЧАЕВИЧ Александр Владимирович - доктор политических наук, доцент; профессор кафедры методологии права и юридической коммуникации Юридического института Российского университета транспорта (МИИТ) (127055, Россия, г. Москва, ул. Образцова, 9, cmp.9; chaevich_alex@ mail.ru)

\title{
РОЛЬ ЯДЕРНОГО ОРУЖИЯ В МИРОВОЙ ПОЛИТИКЕ: ИСТОРИЯ И СОВРЕМЕННОСТЬ
}

\begin{abstract}
Аннотация. В данной статье исследуется роль ядерного оружия не только как военной силы государств, но и как политического фактора в мировой политике. В историческом контексте рассматривается использование ядерного оружия США против Японии в качестве инструмента влияния на своих оппонентов, в первую очередь на СССР. Выявляется значение ядерного оружия в сложившейся после окончания Второй мировой войны Ялтинско-Потсдамской системе международных отношений, особенно в период Карибского кризиса 1962 г. как наиболее острой фазы противостояния двух супердержав. Автор акцентирует внимание на новых подходах к роли ядерного оружия в мировой политике после распада СССР, анализирует современную стратегию ядерного сдерживания России, изложенную в Основах государственной политики Российской Федерации в области ядерного сдерживания от 2 июня 2020 г.
\end{abstract}

Ключевые слова: ядерное оружие, ядерная держава, мировая политика, система международных отношений, Договор о нераспространении ядерного оружия (ДнЯО), ядерное сдерживание, национальная безопасность

$\mathrm{B}$ США ядерное оружие с момента своего создания стало играть не только существенную роль в обеспечении военной безопасности государства, но и в реализации их геополитических интересов.

После окончания Второй мировой войны сложилась система международных отношений, получившая название Ялтинско-Потсдамской. Президент США Г. Трумэн внес серьезные коррективы в уже достигнутые в годы войны соглашения между союзниками о послевоенном сотрудничестве. Ключевым стал постулат: «разговор с русскими с позиции силы». Обосновывая свою позицию по отношению к СССР, Г. Трумэн писал: «Мы должны были перевооружиться сами и перевооружить наших союзников и вместе с тем вести наши дела с Россией таким образом, чтобы они не восприняли наши действия как проявление слабости» 1 .

Ядерный фактор США стал играть важную роль для оказания давления на СССР и его союзников. Соединенные Штаты вынашивали планы реального использования ядерного оружия против Советского Союза. В августе 1945 г. с участием командования ВВС США специально для руководителя американского атомного проекта генерала Л. Гровса был подготовлен секретный документ под выразительным названием «Стратегическая карта некоторых промышленных районов России и Маньчжурии». В документе перечислялись 15 крупнейших городов Советского Союза: Москва, Баку, Новосибирск, Горький, Свердловск, Челябинск, Омск, Куйбышев, Казань, Саратов, Молотов (Пермь), Магнитогорск, Грозный, Сталинск (вероятно, имелся в виду г. Сталино - Донецк), Нижний Тагил. Здесь же указывалось их географическое расположение, приводились сведения о населении, промышленном потенциале, первоочередных целях для бомбардировок. В приложении приводился расчет числа атомных бомб, требуемых для уничтожения каждого из этих

\footnotetext{
1 Россия и США: история вражды. Доступ: https://teddy-boar.livejournal.com/12872.html (проверено 03.11.2021).
} 
городов, с учетом имеющегося опыта Хиросимы и Нагасаки. По мнению авторов документа, для поражения Москвы и Ленинграда требовалось по шесть атомных бомб на каждый из городов ${ }^{1}$.

К началу 1946 г. в США получила обоснование концепция превентивной атомной войны, цель которой заключалась в недопущении разработки в СССР ядерного оружия и превращения его в ядерную державу. Необходимость нанесения превентивного удара по СССР Соединенные Штаты обосновывали потребностью противостояния чуть ли не двойному превосходству вооруженных сил СССР и, соответственно, их способности в считанные дни оккупировать Западную Европу. Как потом стало известно, в 1949 г. в США был разработан план «Дропшот». Хотя концепция превентивной ядерной войны не стала официальной военно-политической доктриной администрации Г. Трумэна, однако в недрах Пентагона и Совета национальной безопасности постоянно разрабатывались военные планы, предусматривавшие использование ядерного оружия в войне против СССР.

Советский Союз стал обладателем атомной бомбы в августе 1949 г. В последующем Великобритания в 1952 г., Франция в 1960 г., Китайская Народная Республика - в 1964 г. стали членами ядерного клуба.

Ядерное оружие внесло в систему международных отношений качественно новые элементы. После того, как СССР стал ядерной державой, ядерный потенциал стал оказывать стабилизирующее воздействие на систему международных отношений. Ранее конфликты между государствами часто приводили к опасной эскалации, а в последующем - и к развязыванию войн, ядерное оружие, в свою очередь, стало оказывать отрезвляющее воздействие на политиков и руководителей разного масштаба. Главы даже могущественных государств понимали, что ядерная война приведет к глобальной катастрофе, которая поставит под вопрос жизнь людей на Земле в целом [Антонов 2012: 16].

Чрезвычайно напряженное политическое, дипломатическое и военное противостояние между СССР и США произошло в октябре 1962 г., Оно получило название Карибского (Кубинского) кризиса. Соединенные Штаты в 1961 г. разместили ядерное оружие в Турции. Ракеты средней дальности «Юпитер» в силу малого подлетного времени могли беспрепятственно достигнуть городов в западной части СССР, включая Москву и крупнейшие промышленные центры страны. Эти ракеты представляли для Советского Союза реальную угрозу, ибо они лишали его возможности нанесения равноценного ответного удара. Ответной мерой Советского Союза стала переброска и размещение на Кубе военных частей и подразделений Вооруженных сил СССР, включая ядерное оружие. 7 января 1963 г. формально считается завершением этого кризиса: тогда представители СССР и США обратились с совместным письмом к Генеральному секретарю ООН с просьбой исключить вопрос о Карибском кризисе из повестки дня СБ ООН.

Карибский кризис 1962 г. мог привести к полномасштабной войне с применением ядерного оружия и, по сути, стал самым опасным за период «холодной войны», когда фактически весь мир стоял на краю ядерной пропасти. США и СССР осознали свою уязвимость и зависимость друг от друга. В последующем таких опасных кризисных ситуаций в отношениях двух стран больше не было.

После Карибского кризиса была пересмотрена и теория ядерной войны. Была разработана концепция «взаимно гарантированного уничтожения» (ВГУ),

1 Забористый план Черчилля. Доступ: https://mikhaelkatz.livejournal.com/14294.html (проверено 03.11.2021). 
согласно которой мир между двумя супердержавами будет сохранен в том случае, если каждая из сторон будет твердо знать, что она не сможет с первого удара уничтожить арсеналы ядерного оружия своего противника, что позволит ему нанести ответный удар. Карибский кризис можно считать переломным моментом в ядерной гонке и «холодной войне». В период с 1960-х по 1970-е гг. в западных странах началось антивоенное движение. В СССР также появились заявления, связанные с возможной угрозой ядерной катастрофы, например, академика А.Д. Сахарова, одного из разработчиков ядерного оружия, призвавшего к ограничению гонки ядерных вооружений и усилению роли общества в принятии политических решений. В устранении Карибского кризиса заметную роль сыграла Организация Объединенных Наций как важный международный институт по урегулированию региональных конфликтов ${ }^{1}$.

В целом можно констатировать, что ядерные потенциалы, прежде всего СССР и США, оказали стабилизирующее воздействие на Ялтинско-Потсдамскую систему международных отношений. Если раньше конфликты между государствами часто приводили к развязыванию крупномасштабных войн, то ядерное оружие становилось преградой для их эскалации. Ни одна из двух сверхдержав не могла пойти на риск широкомасштабного конфликта перед угрозой ответного удара, способного нанести неприемлемый ущерб. СССР и США как бы блокировали друг друга.

В то же время стабильность в рамках Ялтинско-Потсдамской системы была неустойчивой, непрочной. Негативной стороной сложившейся системы стала разорительная гонка вооружений, ставшая впоследствии одной из причин распада Советского Союза [Райский 2014: 148].

Возможность применения ядерного оружия заставила пересмотреть классическую формулу немецкого военного теоретика XIX в. К. Клаузевица: «Война это продолжение политики другими средствами». Достижение поставленных политических целей путем войны оказалось невозможным.

С распадом Советского Союза произошли существенные изменения в Ялтинско-Потсдамской системе международных отношений. Вместе с тем ядерный фактор сохранил свою значимость в отношениях между ведущими государствами мира, прежде всего между Российской Федерацией и США. В военной сфере произошли многочисленные инновации, разработан целый ряд новых видов вооружений, но роль ядерного оружия не изменилась. Оно по-прежнему является олицетворением власти и силы в международных отношениях ${ }^{2}$.

Россия как правопреемница Советского Союза и ключевое ядерное государство в соответствии с Договором о нераспространении ядерного оружия (ДНЯО) определила приоритеты государственной политики в области национальной безопасности с учетом обеспечения ядерного сдерживания как основы стратегического сдерживания [Ядерное оружие... 2006: 31]. Ядерное сдерживание для РФ является высшим приоритетом государственной политики в области военной безопасности и национальной безопасности в целом.

Официальная позиция России по поводу ядерного сдерживания изложена в документе «Основы государственной политики Российской Федерации в

\footnotetext{
1 Карибский кризис 1962 года: хроника противостояния. Доступ: https://ria.ru/20071022 /84921154.html (проверено 03.11.2021).

2 Сохраняющаяся роль ядерного оружия в международном балансе сил. Доступ: //https:// globalaffairs.ru/articles/sohranyayushhayasya-rol-yadernogo-oruzhiya-v-mezhdunarodnombalanse-sil/ (проверено 17.06.2021).
} 
области ядерного сдерживания» от 2 июня 2020 г. ${ }^{1}$ Появление в публичном пространстве документа такого уровня произошло впервые за всю историю Советского Союза и Российской Федерации как его правопреемника. Наша страна впервые за всю историю обладания ядерным оружием опубликовала свое видение его роли и места в общей системе национальной безопасности.

Россия на официальном уровне подтвердила, что ее ядерная политика носит сугубо оборонительный характер, на основе которой строится стратегическое сдерживание. Главная суть политики РФ по реализации ядерного сдерживания заключается в воздействии на военно-политическое руководство потенциального противника за счет убеждения по неотвратимости гарантированного применения Российской Федерацией сил и средств ядерного сдерживания.

Особенность содержания ядерной политики России заключается в том, что она не собирается ни на кого нападать, но предпримет все действия, чтобы нейтрализовать любую агрессию против нашей страны. Такой подход в стратегии активного сдерживания можно охарактеризовать как активную оборону. Россия открыто заявила, что предпринимает и будет предпринимать в дальнейшем все необходимые усилия для уменьшения ядерной угрозы своей безопасности.

В Основах государственной политики Российской Федерации в области ядерного сдерживания определены основные военные угрозы, для нейтрализации которых осуществляется ядерное сдерживание. Эти угрозы, в соответствии с документом, исходят от коллективного Запада и связаны с наращиванием у границ Российской Федерации группировок сил общего назначения, имеющих на вооружении в т.ч. и средства доставки ядерного оружия, с развертыванием систем и средств ПРО, ударных средств различного назначения и базирования, в т.ч. и космического.

Две группы государств выделены в качестве субъектов ядерного сдерживания. К первой группе относятся отдельные государства, а также военные блоки с их участием, которые рассматривают РФ в качестве потенциального противника и обладают ядерным или другими видами оружия массового поражения, а также значительным боевым потенциалом сил общего назначения. Ко второй группе относятся государства, предоставляющие свою национальную территорию для развертывания стратегических наступательных средств и оружия массового поражения другим государствам, которые могут быть использованы против РФ и ее союзников.

Россия впервые публично продекларировала и условия, определяющие возможность применения ядерного оружия. Российская Федерация официально определила своеобразные рубежи, на страже которых будут находиться ядерные силы государства и нарушение которых приведет к сокрушительным ответным действиям.

В конечном итоге содержание ядерной политики России в современных условиях с учетом новых вызовов и угроз военной безопасности направлено на обеспечение понимания потенциальными противниками и их коалициями, что в случае развязывания агрессии против нашей страны и ее союзников будет осуществлено неотвратимое возмездие.

Опубликование данного документа вызвало широкий резонанс в зарубежных средствах массовой информации и получило неоднозначную оценку

\footnotetext{
1 Указ Президента РФ от 02.06.2020 № 355 «Об Основах государственной политики Российской Федерации в области ядерного сдерживания». Доступ: https://www.garant.ru/ products/ipo/prime/doc/74105990/ (проверено 10.06.2021).
} 
среди экспертов в области ядерных вооружений. В средствах массовой информации США и их союзников по НАТО сделан акцент на «агрессивности» политики России, ее стремлении «оправдать создание своих новых стратегических вооружений», «снизить порог применения ядерного оружия» и внести раскол в ряды блока безопасности ${ }^{1}$. В то же время есть и конструктивные публикации по новой ядерной политике России, отраженной в официальном документе 2 .

Российская Федерация стремится придать международную легитимность российским инициативам в области ядерного сдерживания, тогда как США и их союзники наращивают ударные группировки и идут на нарушение системы международных договоров в области контроля над вооружениями. Отечественные и зарубежные эксперты отмечают появление официального документа России в области ядерной политики как желание сдержать развязываемую США гонку вооружений, модернизацию американской противоракетной обороны, милитаризацию космоса и слом международной безопасности.

Таким образом, ядерное оружие с момента его появления и до настоящего времени играло и продолжает играть определяющую роль в политике и стратегии ядерных государств. В современных условиях, да и в обозримом будущем, безъядерный мир, если рассматривать ситуацию объективно, невозможен. Ядерное оружие для РФ играет важную роль как фактор сдерживания. Принципиальная и честная позиция РФ по ядерному фактору в системе обеспечения национальной безопасности изложена в стратегическом документе «Основы государственной политики Российской Федерации в области ядерного сдерживания».

\section{Список литературы}

Антонов А.И. 2012. Контроль над вооружениями: история, состояние, перспективы. М.: РОССПЭН; ПИР-Центр. 245 с.

Райский Д.А. 2014. Ядерное оружие в начале XXI в. - Теория и практика общественного развития. № 5. С. 148-150.

Ядерное оружие после «холодной войны» (под ред. А. Арбатова, В. Дворкина). 2006. М.: РОССПЭН. 556 с.

\section{THE ROLE OF NUCLEAR WEAPONS IN WORLD POLITICS: HISTORY AND MODERNITY}

\footnotetext{
Abstract. The article examines the role of nuclear weapons not only as a military force of states, but also as a political factor in world politics. In the historical context, the author considers the use of nuclear weapons by the United States, which used nuclear weapons against Japan as an instrument of influence on its opponents, primarily the USSR. The article reveals the

1 Об основах государственной политики Российской Федерации в области ядерного сдерживания. Доступ: http://redstar.ru/ob-osnovah-gosudarstvennoj-politiki-rossijskojfederatsii-v-oblasti-yadernogo-sderzhivaniya/?utm_source=yxnews\&utm_medium=desktop\& (проверено 03.11.2021).

2 Американский эксперт похвалил ядерную доктрину России. Доступ: https://rossaprimavera.ru/news/8c041a09 (проверено 03.11.2021).
} 
importance of nuclear weapons in the functioning of the Yalta-Potsdam system of international relations that developed after the end of World War II, especially during the Caribbean crisis of 1962 as the most acute phase of the crisis in relations between the two superpowers. The article focuses on new approaches to the role of nuclear weapons in world politics after the collapse of the USSR, analyzes the modern strategy of Russia's nuclear deterrence that is set out in the Fundamentals of the State Policy of the Russian Federation in the Field of Nuclear Deterrence of June 2, 2020.

Keywords: nuclear weapons, nuclear power, world politics, system of international relations, Treaty on the Non-Proliferation of Nuclear Weapons (NPT), nuclear deterrence

ЮСУПОВА Гурия Ислангараевна - доктор философских наук, главный научный сотрудник Регионального центра этнополитических исследований Дагестанского федерального исследовательского центра РАН (367025, Россия, Республика Дагестан, г. Махачкала, ул. М. Гаджиева, 45;

Huria@list.ru)

МАГОМЕДАЛИЕВА Карина Магомедовна - старший преподаватель кафедры онтологии и теории познания факультета психологии и философии Дагестанского государственного университета (367026, Россия, Ресрублика Дагестан, г. Махачкала, ул. Шамиля, 16; karina557@таil.ru)

\title{
РЕЛИГИОЗНЫЙ ТЕРРОРИЗМ: НОВЫЕ ГЛОБАЛЬНЫЕ И РЕГИОНАЛЬНЫЕ ВЫЗОВЫ
}

\begin{abstract}
Аннотация. В статье исследованы особенности религиозного терроризма на глобальном, государственном, национальном и региональном уровне. В качестве методов научного анализа проблемы использованы системный метод, сравнительный анализ, диалектический подход. Автор проводит сравнительный анализ причин распространения религиозного терроризма в мире, Российской Федерации и в Северо-Кавказском регионе. В результате применения системного подхода предложено авторское определение категории «религиозный терроризм».
\end{abstract}

Ключевые слова: религиозный терроризм, реисламизация, национальная безопасность, Северный Кавказ, регион, экстремизм, радикализация ислама

$\mathrm{C}$ реди ключевых компонентов, формирующих глобальные угрозы и вызовы человечеству, одной из основных является распространение религиозного экстремизма и терроризма [Попова 2021: 41]. Религиозный терроризм в XXI в. превратился в глобальную угрозу первостепенной важности. Исследователи считают, что истоки современного терроризма следует искать в 60-х гг. прошлого века, и связывают его возникновение с распадом ведущих мировых колониальных империй. Однако в результате глобальных геополитических трансформаций последних десятилетий в терроризме произошли серьезные изменения политического, социального, военного характера [Загладин, Путилин 2006: 5]. Только изменив соответствующие условия функционирования социума, можно искоренить опасности экстремизма и терроризма [Дагестан: поиск... 2018: 11]. Метод системного анализа позволяет выделить среди причин распространения террористических практик в современном мире наиболее фундаментальные, или ключевые причины [Зеленцов 2021: 46]. Религиозное возрождение, религиозный фундаментализм, терроризм и экстремизм рассматриваются в качестве факторов, содействующих интенсификации религиозной идентичности [Магомедова 2019: 140]. Современный религиозный терроризм, развивающийся под идеологическим прикрытием исламистских лозунгов, имеет глубокие социальные, политические, социо- 